\title{
A LOOK INTO THE SOCIAL RESPONSIBILITY INITIATIVES OF ONGCL IN RURAL AREAS OF SIVASAGAR, ASSAM
}

\author{
RABISANKARGOGOI
}

Research Scholar, Dibrugarh University, India

\begin{abstract}
Corporate Social Responsibility (CSR) initiatives are being considered as one of the important tool for development of society as it plays a significant role in uplifting the status and standard of living of the society. As major portion of India's population lives in rural society, the growth of India is possible only through the development of rural areas; CSR can play a great role. The present study has been conducted with the corporate social responsibility initiatives of Oil and Natural Gas Corporation Limited (ONGCL) which has been undertaken by the company in the rural areas of Sivasagar District during the financial year 2015-16 and 2016-17. The study also highlighted the plan of action and policies adopted by ONGCL in order to implement and execute the CSR proposals in the study area.

KEYWORDS: CSR, Development, ONGCL, Rural
\end{abstract}

Received: Jun 08, 2020; Accepted: Jun 28, 2020; Published: Aug 17, 2020; Paper Id.: IJMPERDJUN2020775

\section{INTRODUCTION}

"No success in material terms is worthwhile unless it serves the needs or interests of the country and its people."JRD TATA

Economic growth is feasible solely through consumption of inputs out there within the atmosphere and society. The harnessing of natural resources includes a direct impact on the economy, the atmosphere and society at massive. So, the business organizations have the responsibility to deliver one thing back to the society which may compensate the price, a minimum of up to a definite level, at that the firm is working.

India is a developing nation and its main economy is based on agriculture where most of the citizens live in rural areas. As per the Census of India 2011, out of the total population $68.84 \%$ citizens live in villages and $31.16 \%$ lives in urban areas. The development of our country majorly depends on this $68.84 \%$ population where the citizens are not having a proper and sound life. This population is mostly deprived from different facilities and having less access to basics as compared to the citizens of urban areas. It has been noted that most people in rural India are not properly literate, no access to pure drinking water, poor infrastructure and so on. Proper roads are not there in most of the villages and some rural areas are not still having proper electrification which is very basic needs now-a-days. The picture of healthcare is very poor. It has been observed that some people are using the water of ponds and steams for drinking and cooking purposes where pure drinking water is not available. The rural people of our country are facing a lot of challenges which should be solved and curbed down to uplift the life style of them.

Though the Government of India is taking various initiatives to solve these situations, but those initiatives are not sufficient. It is being increasingly recognized that progress and welfare of a society is not only the sole responsibility of the Government, but many more participants need to be involved to attain the development goal. 
Corporate houses have a great role to play in this aspect. Through CSR initiatives, they can deliver something valuable to the local people where they operate and to the society as a whole which will lead to upliftment of standard of living of the people as well as the society.

\section{REVIEW OF LITERATURE}

A number of studies have been carried out in relation to corporate social responsibility and the initiatives undertaken by different business organizations at different levels. It has been a subject for study among research scholars across the world because it has a great impact on the society as well as among the business organizations.

AyubMehar et al (2007) ${ }^{\mathbf{1}}$ has studied the impact of CSR activities on firm's performance with a perspective of Pharmaceutical industry using t-test. The study emphasized on the aspect that whether there is any relationship between CSR activities of a company and its financial performance. The studyhighlighted that there is no significant relationship between corporate social responsibility and firm's financial performance.

Sanjay Pradhan et al $\mathbf{( 2 0 1 0 )}^{2}$ considering 14 public and private sector companies from different industries tried to find out whether the corporates consider the rural people as stakeholders and the kinds of activities undertaken for the rural people under CSR. The study also stressed upon the mode of action of the companies in relation to CSR and the impact on society. The study showed that all surveyed companies present themselves as having their own CSR policy and practices which design and implement CSR initiatives in the vicinity of their works covering entire community.

BidhuKanti Das et al (2011) ${ }^{\mathbf{3}}$ has conducted an explorative study to identify the activities of CSR undertaken by Public Sector Undertakings with special reference to ONGCL in Assam. Through the study, the perception of the local people regarding the CSR activities has been observed along with the impact of those activities on the socio-economic development of the local people. The study revealed a number of activities undertaken by ONGC as CSR in different areas of the state.

Gul Aga et al (2012) ${ }^{4}$ conducted a study on the pharmaceutical companies of Peshawar regarding the impact of CSR activities on the company's financial performance which included a sample of 10 companies which are being studied and analyzed with regression and correlation. It has been observed that there is a strong correlation between dependent and independent variables, which means that there is significant relationship between corporate social responsibility and firms' financial performance

MunazaKanwal et al (2013) ${ }^{5}$ studied that there is a considerable positive relationship between the CSR and Financial performance of the firm, and firms spending on CSR not only benefits firm's continuous long term sustainable development but also enjoy enhanced financial performance.

SaritaMoharana (2013) ${ }^{6}$ made an analysis in relation to CSR practices of Public Sector banks in India which shows that selected banks are making efforts for the implementation of CSR, but are restricted within certain fields which showed a need for better CSR activities by the banks through more and more social development issues link with corporate sector.

Sharafat Hussain (2014) ${ }^{7}$ has conducted a study on forty four companies from different Industries from both public sector and private sector regarding the CSR activities undertaken for rural areas in Indian scenario. The study which 
was based on secondary data has been concluded with that the initiatives undertaken by the selected companies as CSR within different rural areas of India as a whole has vital impact on the society.

Akanksha Jain (2014) ${ }^{8}$ made a study on the mandate of CSR in Indian scenario which revealed both the positive and negative impact for Indian economy. The study revealed some practical examples which cited both positive and negative aspects for the companies with the mandate of CSR provisions. The study concluded as the mandate of CSR to be boon for both the companies and the society.

\section{OBJECTIVES}

The main purpose of the study was to find out the various activities of ONGCL under Corporate Social Responsibility Initiatives. In addition to that an attempt has also been made to identify the focus areas of Corporate Social Responsibility initiatives in the rural areas of Sivasagar district.

\section{METHODOLOGY}

The study on the Corporate Social Responsibility initiatives of ONGCL in the rural areas of Sivasagar district is based on both primary and secondary data. The secondary data were collected from publications of different organizations, articles of different websites, notifications of Ministry of Corporate Affairs, India, notification of Ministry of Heavy industries and Public Enterprises, Companies Act, 2013 and the website of ONGCL. It is not possible to fulfill the objectives of the study with the secondary data alone. Therefore, to fulfill the objectives of the study primary data was collected.

The primary data was collected by a set of questionnaire as well as through personal interview methods. The ONGCL officials of Corporate Social Responsibility Section were being interviewed personally with standard set of questions in order to find out the activities of ONGCL in relation to CSR initiatives and the data from the CSR implementing agencies and the beneficiaries were collected through personal interview method.

In order to carry out the study, data of financial year 2015-16 and financial year 2016-17 were considered. All the initiatives of ONGCL in relation to corporate social responsibility in those two particular financial years are taken into consideration in order to undertake the study.

\section{CORPORATE SOCIAL RESPONSIBILITY (CSR) INITIATIVES OF ASSAM ASSET IN RURAL AREAS OF SIVASAGAR}

The present study is concerned with the CSR initiatives undertaken by Assam Asset ONGCL in the rural areas of the Sivasagar district. There are 882 villages in the district and Assam Asset has taken initiatives in 55 villages during 2015-16 and 2016-17. The initiatives have been executed under specific focus areas and five focus areas have been identified under which CSR activities have been implemented in rural areas of the selected district. Those CSR focus areas in selected villages are: i) Education, ii) Healthcare, iii) Entrepreneurship (livelihood enhancement), iv)Rural Development and v) Water management.

\section{Education}

Education plays a significant role in the development of the society. Its progress cannot be thought of without educating its members. Considering this pivotal issue as most important, it has been reported that ONGCL is spending large amount every year to develop educational infrastructure in various primary and middle level schools and colleges of the district. 
Data available with the CSR branch, Assam Asset shows that amount of Rs.15,64,752 and Rs.28,40,127 has been spent during 2015-16 and 2016-17 respectively.

The initiatives under this focus area of Assam Asset ONGCL during 2015-16 and 2016-17 are presented in Table 1:

Table 1: Showing the Benefits under "Education" in Sample Villages

\begin{tabular}{|c|c|c|c|c|c|}
\hline $\begin{array}{l}\text { SL } \\
\text { No }\end{array}$ & $\begin{array}{c}\text { Name of the Beneficiary } \\
\text { (Institute) }\end{array}$ & Types of Benefit & $\begin{array}{c}\text { No of sample } \\
\text { Villages Covered }\end{array}$ & $\begin{array}{c}\text { 2015-16 } \\
\text { (in Rs) }\end{array}$ & $\begin{array}{c}\text { 2016-17 } \\
\text { (in Rs) }\end{array}$ \\
\hline 1 & $\begin{array}{l}\text { BidyakunjJatiyaVidyalaya, } \\
\text { BokotaKhamun }\end{array}$ & $\begin{array}{l}\text { Financial Aid for Furniture } \\
\text { \& Fixtures }\end{array}$ & 1 & $2,00,000$ & - \\
\hline 2 & $\begin{array}{l}\text { SankardevShishuNiketan, } \\
\text { RupahiMathadang }\end{array}$ & \multirow{2}{*}{$\begin{array}{l}\text { Construction of School } \\
\text { Building }\end{array}$} & 1 & $10,10,752$ & - \\
\hline 3 & $\begin{array}{l}\text { Mezenga Girls High School, } \\
\text { Mezenga }\end{array}$ & & 1 & $3,54,000$ & - \\
\hline 4 & BidyaBhawan, Dimual & $\begin{array}{l}\text { Financial Aid for } \\
\text { Infrastructure }\end{array}$ & 1 & - & $6,32,500$ \\
\hline 5 & $\begin{array}{l}\text { Institute of Tai Studies and } \\
\text { Research, Moranhat }\end{array}$ & $\begin{array}{l}\text { Construction of Scholar's } \\
\text { Cottage }\end{array}$ & 1 & - & $17,19,942$ \\
\hline 6 & Tengapukhuri Junior College & $\begin{array}{l}\text { Construction of Assam } \\
\text { type Building }\end{array}$ & 1 & - & $4,88,185$ \\
\hline
\end{tabular}

(Source: ONGCL office records)

From table 1, it has been observed that out of 55 sample villages, 6 villages (10.9\%) have been benefited under CSR activity during 2015-16 and 2016-17. The benefits were mainly related to development of infrastructure of various educational institutions and also to acquire fixed assets which were provided mainly through financial aids.

\section{Healthcare}

Another vital issue for the development of the people is the better health care facility. With an attempt to assist health care and to create awareness among the people in the district, ONGCL has done a noticeable job. The Assam Asset of ONGCL has been organizing medical camps, constructing Individual Household Latrines (IHHL) and providing financial assistance for making awareness of specific things among the local people.

In 2015-16, the Asset has organized 7 medical camps in rural areas of Sivasagar District which include medical camps organized for flood affected people and awareness programme on HIV/ AIDS. In addition to that, 64 number of IHHL has been constructed under CSR in the rural areas of the district. As per the sources, a total amount of Rs. 13,83,000 spent under this CSR focus area, the initiatives which has been implemented in rural areas.

In 2016-17, the Asset has organized 6 medical camps by providing financial assistance which include awareness programme on Swach Bharat Abhiyan and Smoke free. 924 IHHL has been constructed under the CSR 'Healthcare' focus area in the rural areas of the district. As per sources, a total of Rs. 2,12,90,150 has been spent under this CSR focus area in the rural areas of the district.

Table 2: Showing the Summary of Healthcare Initiatives

\begin{tabular}{|c|l|c|c|c|}
\hline SL No & Benefits & No of Sample Villages covered & $\mathbf{2 0 1 5 - 1 6}$ & $\mathbf{2 0 1 6 - 1 7}$ \\
\hline 1 & Medical Camps & 13 & 7 & 6 \\
\hline 2 & Awareness Camps & 3 & 1 & 2 \\
\hline
\end{tabular}

(Source: ONGCL office records) 
From table 2, it has been observed that 16 villages (29.09\%) have been benefited under CSR activities of Assam Asset out of 55 sample villages. The initiatives were mainly related to organizing of medical camps and awareness camps and each village has been benefited by one initiative only which were organized by providing financial aids to NGOs and Government Departments.

\section{Livelihood Enhancement}

Livelihood enhancement programme plays a great role in the socio-economic development of the community. The rural people of the district is mainly depends on the agriculture that too only for six months. So, providing certain benefits to the local community for the livelihood has a great impact on the standard of living. As per the available data, Rs.17,00,000 has been spent by Assam Asset in each financial year i.e. 2015-16 and 2016-17.

The initiatives undertaken by ONGCL Assam Asset under 'livelihood enhancement' during 2015-16 and 2016-17 are presented in Table 3:

Table 3: Showing the Initiatives under Livelihood Enhancement

\begin{tabular}{|c|c|c|c|c|c|}
\hline SL. No & $\begin{array}{c}\text { Name of the Beneficiary } \\
\text { (Self Help Group) }\end{array}$ & Types of Benefit & $\begin{array}{c}\text { No of sample } \\
\text { Villages Covered }\end{array}$ & $\begin{array}{c}\text { 2015-16 } \\
\text { (in Rs) }\end{array}$ & $\begin{array}{c}\text { 2016-17 } \\
\text { (in Rs) }\end{array}$ \\
\hline 1 & AnkurAtmaSahayak Gut (SHG) & \multirow{7}{*}{$\begin{array}{l}\text { Financial } \\
\text { Aid for Pig farming, } \\
\text { Goatery farming, Dairy } \\
\text { farming and handloom } \\
\text { production }\end{array}$} & 1 & $3,50,000$ & - \\
\hline 2 & $\begin{array}{l}\text { MiliJuliAtmasahayak } \\
\text { Gut(SHG) }\end{array}$ & & 1 & $3,50,000$ & - \\
\hline 3 & Ityadi Self Help Unit & & 1 & $10,00,000$ & - \\
\hline 4 & Arunodoi Self Help Group & & 1 & - & $5,00,000$ \\
\hline 5 & Pubali Self Help Group & & 1 & - & $4,00,000$ \\
\hline 6 & Ma Binapani Self Help Group & & 1 & - & $4,00,000$ \\
\hline 7 & Lakhimi Self Help Group & & 1 & - & $4,00,000$ \\
\hline
\end{tabular}

(Source: ONGCL office records)

From table 3 , it has been observed that 7 villages $(12.72 \%)$ have been benefited under livelihood enhancement programme out of 55 sample villages. Financial aid is being provided to the beneficiaries for Pig farming, Goatery farming, Dairy farming and handloom production purposes. It has been observed that the beneficiaries have got the financial assistance for one time only.

\section{Rural Development}

India is a country where $68.84 \%$ (as per Census 2011) of the people lives in rural areas and mainly dependent on agriculture. So, the development of the country is mainly depends on this $68.84 \%$ people. Corporate Social Responsibility can play a great role in this aspect. Considering this, a specific focus area has been allotted in Schedule VII as 'Rural Development'.

The Assam Asset ONGCL has been initiating different activities under this focus area. Spending huge amount of financial resource, an attempt is being made by the Asset to change the picture of the rural areas in the district. 
Table 4: Showing the CSR Initiatives under Rural Development in 2015-16

\begin{tabular}{|c|l|l|c|c|}
\hline $\begin{array}{c}\text { SL } \\
\text { No }\end{array}$ & \multicolumn{1}{|c|}{ Name of the Beneficiary } & \multicolumn{1}{|c|}{$\begin{array}{c}\text { Types of Benefit } \\
\text { (Financial Aid) }\end{array}$} & $\begin{array}{c}\text { No of sample } \\
\text { Villages Covered }\end{array}$ & $\begin{array}{c}\mathbf{2 0 1 5 - 1 6} \\
\text { (in Rs) }\end{array}$ \\
\hline 1 & $\begin{array}{l}\text { Divine Grace School, } \\
\text { Bogidole }\end{array}$ & FA for procurement of Generator set & 1 & $1,77,817$ \\
\hline 2 & Namtial Navajyoti LP School. & FA for construction of boundary wall & 1 & $2,93,350$ \\
\hline 3 & $\begin{array}{l}\text { Athkhel Sash Bagisa 2 No. } \\
\text { Adarsha LP School }\end{array}$ & FA for construction & 1 & $3,60,000$ \\
\hline 4 & RongpurKalatirtha, Meteka & $\begin{array}{l}\text { FA for repairing and renovation of } \\
\text { Auditorium }\end{array}$ & 1 & $9,00,275$ \\
\hline 5 & Rajabari & $\begin{array}{l}\text { FA for construction of road of proposed } \\
300 \text { beded Multispecialty Hospital }\end{array}$ & 1 & $93,59,500$ \\
\hline 6 & Mechagarh & $\begin{array}{l}\text { FA for construction of MahasatiJoymati } \\
\text { Puthibharal (Library) }\end{array}$ & $1,50,000$ \\
\hline 7 & $\begin{array}{l}\text { Mathurapur HS School, } \\
\text { Mathurapur }\end{array}$ & FA for construction of boundary wall & 1 & $4,52,000$ \\
\hline 8 & $\begin{array}{l}\text { AnkurSanskritik Kendra, } \\
\text { Chalapathar, Lakwa }\end{array}$ & FA for construction of toilets & 1 & $4,10,000$ \\
\hline
\end{tabular}

(Source: ONGCL office records)

From the table 4 , it has been observed that 8 villages have been benefited under rural development focus area in 2015-16. The benefit has been provided as financial assistance to construct School, boundary wall, construction of road, auditorium and bathroom.

The Asset has also initiated certain activities under Rural development during the financial year 2016-17 which are mentioned in Table 5:

Table 5: Showing the CSR Initiatives under Rural Development in 2016-17

\begin{tabular}{|c|l|l|c|c|}
\hline SL No & \multicolumn{1}{|c|}{$\begin{array}{c}\text { Name of the } \\
\text { Beneficiary }\end{array}$} & \multicolumn{1}{|c|}{ Types of Benefit (Financial Aid) } & $\begin{array}{c}\text { No of sample } \\
\text { Villages Covered }\end{array}$ & $\begin{array}{c}\mathbf{2 0 1 6 - 1 7} \\
\text { (in Rs) }\end{array}$ \\
\hline 1 & Metaka & $\begin{array}{l}\text { FA for construction of Dimona Jubilee Park } \\
\text { and Museum }\end{array}$ & 1 & $20,00,000$ \\
\hline 2 & DicialGaon, Dhuliapar & $\begin{array}{l}\text { FA for AC Roofing Sheets for } \\
\text { RajahwaSmashan }\end{array}$ & 1 & $1,49,842$ \\
\hline 3 & $\begin{array}{l}\text { Doba Tinali, Sonari } \\
\text { Desangpani }\end{array}$ & $\begin{array}{l}\text { FA for construction of Training Centre for } \\
\text { handicapped persons }\end{array}$ & $4,60,000$ \\
\hline 4 & Rajabari & $\begin{array}{l}\text { construct the second phase of approach road } \\
\text { in proposed ONGC Multispecialty Hospital }\end{array}$ & 1 & $16,56,000$ \\
\hline 5 & Others* & $\begin{array}{l}\text { Construction of Individual Household } \\
\text { Latrines }\end{array}$ & 9 & $2,92,96,400$ \\
\hline
\end{tabular}

(Source: ONGCL office records)

From table 5, it has been observed that 13 villages have been benefited under rural development during 2016-17. The amount has been on construction of Park and Museum, Training centre and Individual Household Latrines (IHHLs). It has been observed that all the villages have been benefited for once under the CSR of Assam Asset except Rajabari since it has got continuity of CSR activities in 2016-17. So, the number of total villages benefited under rural development during 2015-15 and 2016-17 is 20 (36.36\%). The benefits have been provided in the form of financial assistance for the development of infrastructure.

*The others beneficiaries includes 9 villages i.e. GohainGaon, Gurukhuti, Duwarichika village, Nahat, BandormariGaon, Baputigarh, Bogapara Village, ChakalaPathar Village, Nahat, ChutiaGaon, Kukurpohia, ChetiaGaon, Banmukh, DehingiaGaon, MotokGohainGaon, Banmukh. 
As per the sources, the amount spent under Rural development were Rs. 1,21,02,942 and Rs. 3,35,62,242 during 2015-16 and 2016-17 respectively.

\section{Water Management}

The asset has been associated with works in relation to providing pure drinking water, recharging of ground water through which the health of local community can be improve.

The initiatives undertaken by the Asset during 2015-16 and 2016-17 are presented in Table 6:

Table 6: Showing the Initiatives under Water Management

\begin{tabular}{|c|c|c|c|c|c|}
\hline $\begin{array}{l}\text { SL } \\
\text { No }\end{array}$ & Name of the Beneficiary & Types of Benefit & $\begin{array}{c}\text { No of sample } \\
\text { Villages Covered }\end{array}$ & $\begin{array}{l}\text { 2015-16 } \\
\text { (in Rs) }\end{array}$ & $\begin{array}{l}\text { 2016-17 } \\
\text { (in Rs) }\end{array}$ \\
\hline 1 & $\begin{array}{l}\text { Deopani High School, } \\
\text { Nitaipukhuri }\end{array}$ & \multirow{3}{*}{$\begin{array}{l}\text { Financial Aid for } \\
\text { construction of Drinking } \\
\text { Water facility }\end{array}$} & 1 & $2,50,000$ & - \\
\hline 2 & $\begin{array}{l}\text { Joktali Higher Secondary } \\
\text { School,Sivasagar }\end{array}$ & & 1 & $2,50,000$ & - \\
\hline 3 & $\begin{array}{l}\text { Bhadhara High School, } \\
\text { Sivasagar }\end{array}$ & & 1 & $2,50,000$ & - \\
\hline 4 & Deopani Basti, Galeky & $\begin{array}{l}\text { Financial Aid for providing } \\
\text { deep tuble well }\end{array}$ & 1 & - & $9,56,618$ \\
\hline 5 & Dhitaipukhuri Girls' High School & \multirow{2}{*}{$\begin{array}{l}\text { Financial Aid for providing } \\
\text { water supply facility }\end{array}$} & 1 & - & $3,12,570$ \\
\hline 6 & $\begin{array}{l}\text { Betbari Higher Secondary } \\
\text { School }\end{array}$ & & 1 & - & $3,12,570$ \\
\hline
\end{tabular}

(Source: ONGCL office records)

From table 6, it has been observed that 6 villages (10.9\%) have been benefited out of 55 villages under Water management CSR activities in the Sivasagar district. The Asset has provided financial assistance to various educational institutions as well as villages to have pure water facilities. As per the sources, Rs. 7,50,000 and Rs. 15,81,750 have been spent on CSR activities of Water management during 2015-16 and 2016-17 respectively

\section{FINDINGS OF THE STUDY}

Corporate Social Responsibility can play a great role in the socio-economic development of local community. The corporate houses need to have an objective of social upliftment along with their objective of profit maximization and growth. India having population of $68.84 \%$ in the rural areas as per Census of India 2011 and CSR initiatives of corporate houses can have a great role in the development and growth of those regions.

From the study, the following observations have been made:

- It has been observed that the Assam Asset of ONGCL has undertaken corporate social responsibility initiatives in 55 villages out of 882 villages (6.24\%) in the Sivasagar district during financial year 2015-16 and 2016-17.

- It has been reported that, the Assam Asset ONGCL has initiated CSR activities under five focus areas in 55 villages of the district which are 'Education', 'Healthcare', 'Entrepreneurship', 'Rural Development' and 'Water Management'.

- Under the focus area 'Education', it has been observed that 6 villages (10.9\%) have been benefited during 2015 16 and 2016-17 which has been provided for development of infrastructure of educational institutions. 
- It has been observed that 16 villages (29.09\%) have been covered under the CSR activities of 'Healthcare' which is second highest and the benefits were provided through organizing medical camps and awareness camps.

- It has been observed that 'Livelihood Enhancement' activities covered 7 villages (12.72\%) out of 55 villages and the benefits have been provided to self help groups in the form of financial aid for the purpose of Pig farming, Goatery farming, Dairy farming and handloom production.

- 'Rural Development' covered highest number of villages i.e. 20 (36.36\%) out of 55 villages during 2015-16 and 2016-17. It has been observed that benefits have been provided in the nature of financial aid for construction of road, repairing and renovation of infrastructure, Individual Household Latrines (IHHLs).

- Under the head of 'Water Management', 6 villages (10.9\%) have been benefited out of 55 villages and the benefits have been provided in the form of financial assistance to avail water supply connection.

- It has been observed that the benefits have been provided by the Assam Asset ONGCL mostly in the form of financial aids to different beneficiaries for the development of road, buildings, auditorium, conducting medical camps, encouraging local entrepreneurs and for having pure water facilities.

- It has been observed that only 55 villages have been benefited out of 882 villages of the Sivasagar district in total during the financial year 2015-16 and 2016-17 and all the villageshave been benefited by the CSR activities of the Assam Asset ONGCL for once only except Rajabari as the CSR activity was in continuation in that particular village in both 2015-16 and 2016-17.

- As per the officials of the CSR section of Assam Asset, the organizational plan of action in relation to CSR implementation is in the form of a flow chart which also helps in the monitoring of the CSR activities.

- It has been observed that Assam Asset, ONGCL has been implementing the CSR activities through in-house CSR team along with outside agencies like government registered clubs, NGOs and also in association with government departments.

\section{SUGGESTIONS}

The CSR activities of Assam Asset, ONGCL are Reactive in nature as it has been reported by the CSR branch which leads to the number initiatives depending on the number of proposals received whereas the organization should go for pro-active CSR which will fulfill the needs and objectives of CSR activities.

In order to be successful through Reactive CSR, the Assam Asset is required to receive a sufficient number of proposals from the local community. While it has been observed that only 55 villages have been benefited under the CSR activities of the organization during 2015-16 and 2016-17 from which it can be said that all the rural people are not aware about the CSR activities of the organization. In this regard, the organization can take initiative for awareness camps in relation to CSR activities through which the rural community can be aware in real sense.

The Assam Asset, ONGCL always gives emphasis on the government registered clubs, NGOs or other organization for the implementation of CSR activities for which the organization should get registered and the members of those clubs or NGOs should be properly trained in order to implement the CSR activities. 
As the Assam Asset, ONGCL also has its own in-house CSR team, the organization can undertake a study through which the actual requirements of CSR activities can be identified in the rural areas of the Sivasagar district. It may happen that a particular initiative has been undertaken in a particular village but that initiative may have less importance as the village is in need of different activity. So, an assessment of the requirement of CSR activities would make the picture clearer and initiative taken by organization would be perfect and fruitful.

The Assam Asset, ONGCL should give more emphasis on undertaking the CSR initiatives in rural areas as the development of rural areas would lead to reduction in the migration of local people from rural to urban areas.

\section{CONCLUSIONS}

From the present study, it came to limelight that Corporate Social Responsibility can play a great role in the development of society and it has got tremendous scope for development in rural areas and organization like ONGCL can play a great role in this aspect. Though the study revealed that various CSR activities has been initiated by ONGCL in the rural areas of the Sivasagar district but only $6.23 \%$ of villages (55 no of villages) have been benefited out of 882 villages of the district which is very small for a Maharatna company like ONGCL. The Assam Asset has huge strength to initiate more CSR activities in rural areas of Sivasagar district which would change the prevailing scenario.

The Government is implementing different rural development schemes in different parts of the country but these are not enough. The ONGCL can play a significant role in the development of rural areas through the CSR initiatives not only in Sivasagar district but in all rural areas in the state of Assam and the country as a whole.

\section{REFERENCES}

1. AyubMehar and Farah Rahat (2007): “Impact of Corporate Social Responsibility on Firm's Financial Performance”, "South Asian Journal of Management Sciences", Vol. 1, Issue 1, pp 16-24

2. Sanjay Pradhan, AkhileshRanjan(2010): “Corporate Social Responsibility in Rural Development Sector: Evidences from India”, "School of Doctoral Studies (European Union) Journal”, pp 139-147

3. BidhuKanti Das, Prof. P. K. Halder(2011): "Corporate Social Responsibility Initiatives of Oils PSUs in Assam: A case study of ONGC”, “Management Convergence”, Vol. 2. Issue 2 pp 75-85

4. Anupam Sharma and Ravi Kiran(2012): “Corporate Social Responsibility Initiatives of Major Companies of India with Focus on Health, Education and Environment”, , "African Journal of Basic \& Applied Sciences” Vol 4 Issue 3 pp 95-105 ISSN 2079-2034.

5. SaritaMoharana(2013): “Corporate Social Responsibility: A Study of Selected Public Sector Banks in India”, "IOSR Journal of Business and Management", Volume 15, Issue 4 e-ISSN: 2278-487X, p-ISSN: 2319-7668. PP 01-09.

6. Mahto, Vikas, and Harveer Singh. "Effect of Temperature and Pour Point Depressant on the Rheology of Indian Waxy Crude Oil." International Journal of General Engineering and Technology (2013).

7. Akanksha Jain(2014): "The Mandatory CSR in India: A Boon or Bane”, "Indian Journal of Applied Research", Volume 4 Issue 1 ISSN 2249-555X.

8. Pooja Rani, MS Khan(2015): “Corporate social responsibility (CSR): An analysis of Indian Banking Sector", "International Journal of Applied Research” Vol 1 Issue 11 ISSN Print: 2394-7500 ISSN Online: 2394-5869 pp 304-310. 
9. Mukut, Kalita, and Devi Arundhuti. "Uptake of metals by four commonly available plant species collected from crude oil contaminated sites of Lakowa Oil Field (Assam)." International Journal of Agricultural Science and Research (IJASR) 2.4 (2012): 121-134.

10. Nidhi Malik(2016): “Corporate Social Responsibility in Indian Banking Industry: Study on Attempts of HDFC Bank”, “International Journal of Research - Granthaalayah”, Vol.4 Issue8 ISSN-2350-0530(O) ISSN-2394-3629(P) pp 62-74.

11. Sheik, M N Mohamed Abusali, and D. Andrews Scott. "Financial Analysis and Performance of Oil and Natural Gas Corporation-for the Period of 2007 to 2012."International Journal of Accounting and Financial Management Research (IJAFMR) ISSN 2249-6882 Vol. 3, Issue 4, Oct 2013, 81-88

12. Notifications issued by Ministry of Corporate Affairs(MCA), Government of India.

13. Notification Issued by Ministry of Heavy Industries and Public Enterprises on 21 st October, 2014

14. De, L. C., and D. R. Singh. "Natural resources in North East region of India." International Journal of Agricultural Science and Research 7.5 (2017): 51-66.

15. Companies Act 2013 with Rules, Taxmann's Publication, (2015) ISBN 978-93-5071-586-4. 